\title{
PERCEPTUAL ETYMOLOGY, OR THREE TURKISH CULINARY TERMS IN CROATIAN AND SLOVENE, AND A POLISH SOCIAL TERM INTELIGENCJA 'INTELLIGENTSIA'
}

Keywords: etymology, Polish, Croatian, Slovene, Turkish

\begin{abstract}
This paper has been inspired by Roberto Dapit's study of 2021. My aim is to show the sense of using what can be called "perceptual etymology" (analogically to "perceptual dialectology") along with and in contrast to the "scholarly etymology".
\end{abstract}

1.

The first stimulus to focus on the words mentioned in the title of this paper came from an article recently published by Roberto Dapit (2021). The study concerns Turkish culinary terms, as used in Slovene. The backbone of the article are three Slovene words: čorba (« Turkish çorba 'soup'), burek (« Turkish börek 'filled pastry') and čevapčič (« Turkish kebap 'a grilled meat dish') and the discussion encompasses cultural and sociolinguistic aspects rather than purely etymological ones. I, by contrast, am going to discuss the etymological aspect of the terms.

The fact that R. Dapit has called these words turchismi is conspicuous because the Ottomans never conquered Slovenia and the Slovenes never organized expeditions to Turkey, which means that they have never actually had direct contact with Turks or Turkish. Besides, R. Dapit has limited his observations to the second half of the 2 oth century, that is a period long after there was an Ottoman presence to the north of the modern Rumelian border of Turkey. It is, thus, clear that the so-called Turkish loanwords in Slovene have, as a matter of fact, been borrowed from Croatian 
as an intermediary language. Dapit is aware of the problem and he quite correctly says the words were introduced to Slovene "per mediazione del serbo-croato" (Dapit 2021: 31 and fn. 1). He also explains, in fn. 2, that he uses the term serbo-croato as an umbrella term for Croatian, Bosnian, Serbian and Montenegrin. I would rather suggest it is more accurate to speak of Croatian alone because Bosnian and Montenegrin came into existence only after the collapse of Yugoslavia at the very end of the 2oth century and Slovene could, for geographical reasons, have had only very limited contact with Serbian. Thus, Croatian is the only realistic mediator between Turkish and Slovene unless historians will have found documents pointing to a, say, Bosnian restaurant owner who migrated to Slovenia and made his Bosnian food names popular in Slovenian. Until such time, Croatian is the most possible source of the turchismi in Slovene. But why, then, does Dapit call them this way instead of speaking of Croatian or, maybe, (Serbo-)Croatian loanwords?

\section{2.}

The problem seems to have a broader background involving the question - still not quite clear to everybody - whether a loanword should be classified according to its direct or the ultimate source. The main problem is that we are quite often not in a position to find the definitely ultimate source and if we do find one it generally sounds so differently and has such a different sense that its connection with its modern reflex, that has been our starting point, cannot be possibly explained. That is why modern etymology definitely demands classifying loanwords by their direct source, even though that methodological requirement is more often than not ignored by non-etymologists (and also some conservative etymologists).

From an etymological point of view all these words should be called "Croatianisms in Slovene". Nevertheless, etymologies presented in Dapit's paper are generally correct (apart from the fact that (Serbo-)Croatian burek should better be derived from Turkish dialectal bürek than from the literary form börek).

There are some problems, however, connected with (Serbo-)Croatian ćevapčić > Slovene čevapčič 'grilled meatball'. The structure of the word is clear: ćevap (< Turkish kebap) + the (Serbo-)Croatian diminutive suffix -čić, as in sin-čić < sin 'son', kamenčić < kamen 'stone'. The semantic and cultural aspects are, nonetheless, a bit less perceptible. The type of kebap best known in Europe (actually being a cultural reflex of what is called döner kebap in Turkish) looks different from the Balkan ćevapčić meatballs that can better be associated with Turkish köfte and, indeed, the (Serbo-)Croatian ćevapčić is called qofte in Albanian. It is, thus, hardly possible to interpret the Balkan Slavic ćevapčić as small forms of the Turkish kebap. One should rather, for semantic reasons, accept Turkish şiş kebap = şiş köfte 'chopped meat placed on a skewer and grilled' as the correct etymon. It was probably due to the high frequency of occurrence of the word in the Balkans, as well as to obviousness of the most preferred form of the dish, that the term şis kebap was shortened to just kebap (and then altered into ćevap in Serbian and Croatian, albeit with the meaning 
of şiş kebap). It is also most likely that the shortening of the form without changing the meaning first occurred in Rumelian Turkish dialects and was only afterwards transmitted to (Serbo-)Croatian.

The Slovene word čevapčič should be classified as a Croatian loanword whose form and sense cannot be possibly derived directly from Turkish. The situation with čorba and burek is somewhat different.

The word burek 'flaky pastry with a non-sweet filling' < Turkish dialectal bürek (= Turkish literary börek) is a genuinely Turkic word (see KEWT 92 sq.). The vocalic change of the Turkish $\ddot{u}>$ Slovene $u$ would also have occurred if the word had been borrowed directly from Turkish. ${ }^{1}$ That means that no purely linguistic argument in favour of the Croatian source of the Slovene word can be presented. It is only the history of contacts that suggests the intermediary role of Croatian.

Unlike burek, Turkish çorba 'soup' (> Croatian čorba > Slovene čorba id.) is a loanword in Turkic. Its ultimate etymon is Persian šū $r b \bar{a}<\check{s} \bar{o} r-p \bar{a} k$ 'cooked with salt' (see KEWT 115). ${ }^{2}$ Thus, the Turkish form is just one link in the borrowing chain, neither the ultimate nor the direct one: Slovene $<$ Croatian $<$ Turkish $<$ Persian. Why do we so readily classify the word as Turkish?

\section{3.}

Let us try now to collect the data we have at our disposal in a table:

1

The Slovene
word

čevapčič

burek

čorba
2

The direct

borrowing source

Croatian

Croatian

Croatian
3

Today associ-
ated with

Today associ-

Formally evolved in
5

Semantically

and culturally evolved in

Turkish

Turkish +
Croatian

Turkish +

Croatian

Turkish

Turkish

Turkish

4.

There are, as it seems, various possible ways of characterizing each of these words. The purely etymological, scholarly criterion is the direct source (Croatian $>$ Slovene). As can be seen, the popular impression does not coincide with the scholarly insight but it should not be rejected as wrong because it is not quite wrong - it shows

Phonetically cf. Slovene bukselj 'fool, idiot' < German Büchs(e)le, diminutive < Büchse 'can, tin'.

2 Typologically cf. the Russian soup name ssoljanka〉 sol'anka $<$ sol' salt'. 
how the words are perceived by those who use them and that fact is not irrelevant, e.g. they could, irrespective of their Croatian origin, fall victim to imaginary antiTurkish purists trying to delete all Turkish words in Slovene. The association in column 3 cannot be labelled "folk etymology" because no etymon is suggested and no original meaning is "reconstructed", that is no rational argument is offered as is commonplace in the folk etymology. Therefore I would rather suggest to call:

\section{Column 2 - (scholarly) etymology \\ Column 3 - perceptual etymology}

Even though the perceptual dialectology began as early as "in 1930s in the Netherlands but only gained greater impetus in 1980 os and 1990s, owing to the works of D.R. Preston" (K. Stachowski 2017: 221) the concept of perceptual etymology seems to have not been, thus far, the subject of scholarly insights. Three words are of course not sufficient to draw far-reaching conclusions. Nevertheless it seems rather certain that perceptual etymology generally ignores formal changes and highlights the memory of the cultural area to which the word is supposed to have originally belonged.

Most people think the Polish word inteligencja 'a social class of educated people engaged in mental labour' is a loanword from Latin. However, the Latin word intelligentia meant something different, that is 'intelligence, capacity for thinking'. The social term inteligencja was coined by a Polish philosopher Bronisław Trentowski (1808-1869) who first used it in his book (Trentowski 1843) on the "relation of philosophy to cybernetics, or the art of ruling nations" (see Billington 1980: 231). Why do average Poles think the word is Latin? Because their perceptual etymology is based on the belief that mental and intellectual vocabulary comes from Latin. Semantic evolution or differences do not belong in that belief. And why did Stanisław Kochman (1935-2010), a Polish Slavicist claim that the word inteligencja 'intelligentsia' must have come into being in Prussia? First, he did not know the attestation in Trentowski's book but he knew that the oldest recordings of the word were found in the Grand Duchy of Posen/Poznan as well as that German encyclopaedias attested the word Intelligen $z$ with the meaning 'intelligentes Wesen', that is 'intelligent being/creature' in the 1920's (Kochman 20053: 287). Again, the perceptual etymology directed Kochman to Germany as the source of many Polish scientific terms and that awareness was stronger than the observation that the German word had a psychological meaning rather than a sociological one. Thus, the Latin word evolved twofoldly: as a psychological term in Germany and as a sociological one in Poland. Kochman was probably right in his further claim: the Polish word was borrowed into Russian (интеллигенция, from 1861 on [Kochman 2005: 283]) and then, via the great Russian literature, into the other European languages, among others into English: intelligentsia (Kochman 2005: 289).

First edition: Kochman S. 1988. Pol. inteligencja, ros. интеллигениия 'warstwa społeczna ludzi wykształconych zajmujących się zawodowo pracą umysłową' - nazwy rodzime czy zapożyczone (z badań nad słowiańskim słownictwem zapożyczonym). - Basaj M. et al. (eds.). Wokót języka. Wrocław: Zakład Narodowy im. Ossolińskich: 211-22o. 


\section{References}

Billington J. 1980. Fire in the minds of men. Origins of the revolutionary faith. New York: Transaction Publishers.

Dapit R. 2021. Vicende de alcuni turchismi della gastronomia nella lingua slovena. - Occhiali 8: 31-56.

KEWT = Stachowski M. 2019: Kurzgefaßtes etymologisches Wörterbuch der türkischen Sprache . Kraków: Księgarnia Akademicka.

Kochman S. 2005. Studia nad słownictwem i frazeologią słowiańską. Opole: Wydawnictwo Uniwersytetu Opolskiego.

Stachowski K. 2017. An experiment in labelling Draw-a-Map maps. - Studies in Polish Linguistics 12.4: 221-240.

Trentowski B. 1843. Stosunek filozofii do cybernetyki, czyli sztuka rządzenia narodem. Poznań: J. K. Żupański. 
